\title{
The Levinson Theory in the Detection of Spelling Errors Among Dyslexic Children
}

\section{Language}

KEYWORDS : Levinson Theory, Spelling

Mastery, Dyslexia, Malay Language

\section{Wan Muna Ruzanna Wan Mohammad}

\section{S. Vijaya Letchumy}

Miss-Department of Malay Language, Faculty of Modern Languages and Communication, University Putra Malaysia

Assoc. Prof. Dr.-Department of Malay Language, Faculty of Modern Languages and Communication, University Putra Malaysia

\section{ABSTRACT}

In 2004, Malaysian Education Ministry (KPM) had begun its "Pilot Program of Dyslexia-Specific Learning Problems", and currently in 2012 there are already 49 primary schools with 86 dyslexia classes throughout Malaysia. This study focuses on the detection of spelling errors in the Malay Language essay-writing done by dyslexic children all across Terengganu, Malaysia. This spelling error detection was centralized on the Levinson Theory, 1994. This theory has shown seven aspects of errors in the writing done by dyslexic children, namely errors in terms of (i) elimination, (ii) transfer, (iii) insertion, (iv) replacement, (v) reversal, (vi) wild guess, and (vii) condensation. This study was done on eight dyslexic children aged 10 years old registered with the Society Welfare Department, Terengganu and all of them were adopted as the sample of the study. The study findings have demonstrated that elimination, replacement and wild guess were among the most committed by the subjects. Meanwhile, in terms of transfer, reversal and condensation, they were the lowest committed by the subjects. The study outcome had given priority to the instructors of the dyslexic class, for them to make some improvements on the teaching and learning strategies in facilitating the process of mastering the spelling for the subject of study. The variety of therapies used to promote spelling mastery can be used as a consolidation in learning and to strengthen exercises both in school and outside class hours.

\section{BACKGROUND}

Malaysian Education Ministry (2010), in the Malaysian Education Plan statements from 2001-2010, states that educational opportunity for all is an aim held by the Malaysian education including the learning of children with special needs. The establishment of several schools for children with special needs has been upgraded as to accommodate the educational needs of these children in national schools (the Master Plan of Educational Plan, 2010). Based on the Educational Act (1996) amended in 2002, all children aged six years and above are made compulsory to go to school. Meanwhile, for the Disabled Act (2008) it is established that the educational opportunity for the disabled people cannot be exempted. Thus, it is harmonious with the government's initiatives to provide education for children with special needs.

In developing excellent human capital among children with special needs, the national education system must be of quality, relevant and holistic. Individuals with excellent education need to expand their self-potential , until the optimum level so that the individuals can help the coming generations and are able to compete and have the marketability in anything they produce for use in the educational field. As responsible citizens to the nation, religion and country, the individuals must inculcate good, noble values in every movement and actions they demonstrate.

According to Lyon et al. (2003), dyslexia is a specific learning problem that roots from neurobiology. The main characteristics identified are the weaknesses in identifying words, spelling and also recording words when reading. The dyslexic learning issue is classified into six characteristics and these areas areas (i) the difficulty in using the language, (ii) the imbalance with intellectual ability, (iii) the struggle when reading printed materials, (iv) not being able to write eloquently and precisely-the difficulty in copying words from the board or book, (v) tired eyes after concentrating on the writing for several minutes, and (vi) limited concentration (Madhya Zhagan, 1999; Lee, 2008). According to the study done by Mercer (1997), Hammond and Hugges (1996), also Spafford and Grosser (1996), the real cause of dyslexia is divided into three, the aspect of hereditary or genetics, biology and maturity. This study has proven that dyslexic individuals have family backgrounds associated with dyslexic syndrome caused by chromosomes 15,1 and 16 that can be passed down genetically. Julie Williams \& Michael C O'Donovan (2006), in their study related to The Genetics of Development Dyslexia have proven that the presence of genes influence the development of dyslexia involving certain chromosomes. This study is able to identify genes which becomes a sort of disturbance in terms of biasness or complex so much so that there would be an occurrence of dyslexia to an individual.

Dyslexic children constitute some of the children who have difficulty in learning. They suffer from various problems, some of which include the problem in communicating, listening, writing, reading and counting. Most dyslexic children have good potential in their intelligence but they have lower learning potential than other normal children (Delphie, 2006). Therefore, according to Daniels (2009) and McLeskey, Rosenberg, \& Westling (2008), the learning environment for children with special needs should be segregated from children from the mainstream in order to create a more focused surrounding.

With reference to the writing issue confronted by dyslexic children, Yusop bin Hj. Malie \& Walter Alvin Jiniti (2010) have initiated a study with regards to "Disgrafia dan Cara Membantu: Kajian Kes Ke Atas Murid Program Integrasi Pendidikan Khas" (Dysgraphy and Ways To Help: Case Study on Students of Special Education Integrated Program). The focus of this study is to analyse the problems that lie in the mechanism of writing amongst dyslexic children. This study involved a child from a learning problem class from the Special Education Integrated Program in Kuching. The methods used in this research include observations on the child's behavior and writing test. From the observation, it is found that the problems are manifold- the way he holds the pencil, letter formation, inconsistent letter size, and inaccurate writing technique.

A member of the Optometry Department, Allied Health Science Faculty, UKM, Ai Hong Cheng and Noor Surini Mohamad (2002) has done a study on "Kekeliruan Mengecam Huruf B-D-P-Q di kalangan Kanak-kanak Prasekolah" (The Confusion in Detecting Letters B-D-P-Q Among Pre-schoolers). In this research, researchers have focused on 3 types of confusion, namely inverted reversal, reversal-type and mirror image (contrasting image). 61 Malay pre-school children were made the subject of this study. To test the confusion, children were instructed to write b-d, p-q on a paper separately. Other than that, the subject was instructed to detect the test plates comprising of 12 pairs of letters such as b-q, p-d, p-d, and so on as to test the confusion to detect these letters. Confusion in detecting is higher than the confusion arising from re-writing. Children with the problem of detecting the letters tend to be more complex as compared to children who have issues with writing as has been stated by 
Barnard et al. (1996).

\section{METHODOLOGY}

The Dyslexia Syndrome Theory was pioneered by Levinson (1994). He has stated that dyslexia comes in three problematic areas: the reading aspect, the writing aspect and arithmetic. Therefore, in the first two aspects, Levinson has outlined seven mechanisms of errors, which are (i) transfer, (ii) insertion, (iii) replacement, (iv) elimination, (v) condensation, (vi) reversal, and (vii) wild guess. Most dyslexic people would demonstrate the signs of not being able to balance their capacity to memorize letters, the sounds of letters, and word combination as they forget easily. They have exercised various skills and efforts to prevent their weaknesses being detected by the teacher.

Researcher has employed several methodologies including library study, observation, interview, and tests. All these approaches had been adopted to obtain precise findings, and which tally with the objectives of the study.

This research made use of $100 \%$ study subjects in Terengganu. There are 25 dyslexic students from 3 Dyslexia Plot Schools in Terengganu who have been acknowledged as People With Disability (OKU) of various ages. Thus, to meet the objectives, the researcher had chosen all Year Five dyslexic students totalling 8 students from the three schools SK Padang Hiliran, SK Chukai, and SK Tengku Mahmood 2. All the data obtained from the subjects' writings were analysed qualitatively by making their essay manuscripts the primary source of this research.

\section{STUDY FINDINGS}

The failure of dyslexic children in their language proficiency, such as reading, writing and spelling, which is consistent with their age level and their capability stems from the confusion arising in the minds of the children (Wold Federation of Neurology, 1968). In Levinson's Theory (1994), Levinson has proposed seven mechanisms of writing errors committed by dyslexic people (i) transfer, (ii) insertion, (iii) replacement, (iv) elimination, (v) condensation, (vi) reversal, and (vii) wild guess. The existence of these mechanisms propels the researcher to see just how far would these errors be committed by the dyslexic students particularly in Terengganu.

\section{Elimination}

Elimination as an error is divided into two sections, namely word-elimination and letter-elimination. Based on the analysis done on the subjects' papers, it is found that word-elimination is not the case here and thus, the focus of errors will only be on letter-elimination.

Table 1.1: Error Mechanism In Terms of Elimination

\begin{tabular}{|l|l|l|l|l|}
\hline SK 1 & di bangku & Keperluan & perlu & membuat \\
\hline & memerlukan & Perasaan & pengguna & memerlukan \\
\hline SK 2 & di bangka & berubah-ubah & mempunyai & \\
\hline & kehendaki & Pelbagai & berbelanja & keperluan \\
\hline & sesuatu & Pengguna & ingini & berbelanjalah \\
\hline SK 3 & di bangku & Barangan & seperti & memerlukan \\
\hline & mengikut & Nafsu & perasaan & berubah-ubah \\
\hline & pilihan & Sesuatu & jadilah & pengguna \\
\hline SK 4 & barangan & Personalannya & $\begin{array}{l}\text { berubah- } \\
\text { ubah }\end{array}$ & untuk \\
\hline & sesuatu & Membuat & pengguna & $\begin{array}{l}\text { berlumba- } \\
\text { lumba }\end{array}$ \\
\hline SK 5 & $\begin{array}{l}\text { Pengguna } \\
\text { 2) }\end{array}$ & & & \\
\hline SK 6 & digunakan & pengguna (2) & barangan & terutamanya \\
\hline SK 7 & di bangku & Penukaran & mengikut & perasaan \\
\hline & berfikir & Membuat & $\begin{array}{l}\text { pengguna } \\
(2)\end{array}$ & $\begin{array}{l}\text { berlumba- } \\
\text { lumba }\end{array}$ \\
\hline & golongan & & & \\
\hline SK 8 & $\begin{array}{l}\text { keperluan } \\
\text { (2) }\end{array}$ & Sekadar & hendak & pengguna \\
\hline & membeli & & & \\
\hline
\end{tabular}

(Source: Field Research, 2012)
(1) Original : : Kita masih di bangku sekolah. Sentence

SK $1 / 2 / 3 \quad$ : Kita masih di banku sekolah.

SK $7 \quad$ : $\quad$ Kita masih di baku sekolah.

(2) Original : : ... penukaran dengan barangan yang Sentence kita kehendaki.

SK $2 \quad$ : ... penukaran dengang baranan yang

SK 3/6 : $\quad$ kita penukaran dengan barang kita kehendaki.

SK $4 \quad$ : $\quad$... penukarang dengan baragan yang kita kehendaki.

What is shown above is the sample of error in terms of letterelimination done by the subjects of this study during the writing test. Referring to the samples of sentences (1), SK 1, SK 2, and SK 3 had made a mistake by writing the word <bangku> to become <banku>, the word was written with the letter $<\mathrm{g}>$ eliminated. Meanwhile, SK 7 wrote /bangku/ as <baku>. SK eliminated the letter $\langle\mathrm{n}\rangle$ and $\langle\mathrm{g}>$ in the word /bangku/. Table 1.1 above shows that SK 1, SK 2, SK 3, and SK 7 are among the SK who had done letter-elimination the most in their writing.

Based on sentence (2), the problem here is in the words $<$ barangan $>$ and $<$ kehendaki $>$. SK 2 had done two spelling errors in the above sentence, which is wrongly writing the word $<$ barangan $>$ to become $<$ baranan $>$ by eliminating the letter $<$ g $>$ and $<$ kehendaki $>$ becomes $<$ kehedaki $>$ by eliminating the letter $<$ n $>$ on the word.

SK 3 and SK 6 had written <barangan $>$ as $<$ barang>. SK 3 and SK 6 had dropped the letter $<\mathrm{a}>$ and $<\mathrm{n}>$ at the end of the word $<$ barangan $>$. According to the $4^{\text {th }}$ Edition Kamus Dewan (2005), the word < barang $>$ means 'item' while < barangan $>$ means items able to be sold and bought. Thus, the word $\langle$ barang $>$ cannot be appropriately used in the sentence above because it a business activity. The same thing almost happens to SK 4, where the word <barangan $>$ was written as <baragan $>$, where the letter $<\mathrm{n}>$ was dropped.

(3) Original Sentence

:... berbelanja mengikut keper luan ataupun sekadar menurut nafsu.

SK $1 \quad$ :... berberlanja mengikut kepeluan ataupuh Sekadar menurut nafsul.

SK $2 \quad$ : ... berbelanja menekok kePeruan atauaPun Sekadar menutuk nafsu.

SK $8 \quad$ : ... berberlanja memikut kepeluan atau pun sekada menurut nasut.

The analysis further shows that in sentence (3) SK 1 and SK 8 had dropped the letter $<r>$ at the word $<$ keperluan $>$ and it became <kepeluan>. In sentence (3), SK 8 had committed two errors of letter elimination, namely in the word $<$ keperluan $>$ and $<$ sekadar $>$. For the word <sekadar $>$, SK 8 had dropped the letter $<\mathrm{r}>$ in the end of the sentence making it to read $<$ sekada $>$. Meanwhile, SK 2 had eliminated the letter $<\mathrm{l}>$ at the word $<$ keperluan $>$ and it became <keperuan $>$.

This is normal among dyslexic people as their long-term memory is very limited in remembering phonetic procedures in both phonetics and morphology. Dyslexic children are able to generate their short-term memory in daily activities and also in their learning. Their memory will often center on something that they frequently see and do, and the environment can also influence their memory and learning experiences.

\section{Transfer}

Error in terms of transfer shows how SK spells and writes a word by reversing the letter in a word and reversing the syllable in a word. Examples are given below: 
\begin{tabular}{|l|l|}
\hline$(4)$ & Wang digunakan sebagai alat untuk membuat
\end{tabular} Original Sentence penukaran ...

SK 5 : ... di guna kan seDagai atal untuk membuat

Guided by sentence (4) above, SK 5 had made a mistake in terms of the transfer of the position of the letter back to its original place. For the word <alat> as found in sentence (4), SK 5 had spelt the word <alat $>$ to become <atal $>$. The position of the letter $<\mathrm{l}>$ after the letter $<\mathrm{a}>$ was replaced by the letter $<\mathrm{t}>$. The same goes with the position of the letter $<t>$ at the end of the word which was replaced by the letter $<\mathrm{l}>$. This is because of the speed rate of the pupil of the eyes while reading, which causes dyslexia sufferers to read the end-part of the word first and vice versa. Visual perception or interpretation refers to the process of interpreting and systematizing visual information, The Visual Theory in dyslexia studies that take into account visual distraction in the difficulty of processing letters and words (Lovegrove et.al., 1980; Livingstone et. al, 1991; Stein \& Walsh, 1997). This may be caused by the unstable binocular fixation, vergens issues, or an enhanced crowding phenomenon.

\section{Insertion}

Malay Language writing establishes four types of insertion that often occur, namely the insertion of -el-, -em-, -in-, and -er-. Typically, insertion occurs in the root words and produces affixes, for example the word <tunjuk> inserted with -el- which creates a word <telunjuk>. Same goes with the word <kuning> becoming <kemuning $>$, <sambung $>$ becoming <sinambung $>$, and $<$ kuping $>$ becoming < keruping $>$. However, the same thing is noted through the error of insertion while the sound is pronounced and spelt, for example the word <piano>. The word $<$ piano $>$ is pronounced as such- /pi.ya.no/. Therefore, dyslexic children will normally spell <piyano $>$. This is also, to a certain degree, influenced by the oral version and local dialects, especially the Terenggnu Dialect seeing that this research was carried out in Terengganu.

Table 1.2: Error Mechanism In Terms of Insertion

\begin{tabular}{|l|l|l|l|l|}
\hline SK 1 & berberlanjalah & barangangan & pelpabagai & berberlanja (2) \\
\hline SK 2 & biyasanya & $\begin{array}{l}\text { berubah- } \\
\text { rubah }\end{array}$ & & \\
\hline SK 3 & sembelum & keperluayaan & biyasanya & \\
\hline SK 4 & berbelanjarlah & semjumlah & kerperluan & memeperlukan \\
\hline & berbelanjar & & & \\
\hline SK 5 & berubah-rubah & & & \\
\hline SK 6 & pernukaran & biyasanya & perniaga & \\
\hline SK 7 & mermerlukan & semjumbalah & kerperluan & \\
\hline SK 8 & berbelanjarlah & semjumlah & berberlanja & berubah-rubah \\
\hline & ankan & & & \\
\hline
\end{tabular}

(Source: Field Research, 2012)

(5) Original Sentence: Biasanya perasaan kita akan berubahubah ...

SK 2 : Biyasanya perasanga kita akan berubah- rubah ..

SK 3 : Biyasanya perasan kita akan berubar ...

SK 5 : Biasanya perasaan kita akan berubah-rubah ...

SK 6 : Biyasanya perasaan kita akan berubah-ubah ...

SK 8 : Biasanya perasang kita anka berubah-rubah...

(5) demonstrates an error in terms of insertion for the word $<$ biasanya > and < berubah-ubah>. Three out of eight SK had done an insertion error on the word < berubah-ubah $>$ by spelling it as < berubah-rubah>. SK identified, namely SK 2, SK 5, and SK 8 had inserted the letter $<r>$ on the word $<$ berubah-ubah $>$ and made it become <berubah-rubah>. This is due to the habitual way of pronouncing it continuously. Dyslexic children cannot be burdened with a variety of formula or language patterns as they do not like to memorize and remember the formula. They would instead stick to what they are familiar with, so much so until there is consolidation that can alter their minds to accept something new.

For SK 2, SK 3 and SK 6 they had inserted the letter $<y>$ when spelling the word <biasanya $>$ by turning the word into < biyasanya>. SK 2, SK 3, and SK 6 had spelt the word the way it sounds, spelt as <biyasanya>. Indeed, <bia> was read <bi.ya>, but the letter $<y>$ needs to be dropped because the letter $<$ a $>$ also has the same sound when spelt <ya>. Insertion will occur when SK spells a word based on the sound of the syllable without making an exception towards the additional sound whereby there exist letters that do not have to be spelt clearly.

\section{Replacement}

Among the letters which are error prone would be the letter $<\mathrm{h}>$ replaced by the letter $<\mathrm{n}>$ while spelling,for instance in $<$ digunakan $>$ becoming < digunakah $>$, and < ataupun $>$ becoming <ataupuh>.

Table 1.3: Error Mechanism In Terms of Replacement

\begin{tabular}{|l|l|l|l|l|}
\hline SK 1 & diguh(n)akan & te(a)npa & e(i)ibu bapa & sejumlam(h) \\
\hline & akah(n) & ataupuh(n) & bak(r)angan & biju(a)k \\
\hline SK 2 & tam(n)pa & ade(a)kah & be(i)jak & menuruk(t) \\
\hline & m(b)arangan & Membuan(t) & Semuaah(nya) & \\
\hline SK 3 & big(j)ak & bat(r)ang & tam(n)pai & menuruk(t) \\
\hline & ha(e)ndak & membual(t) & & \\
\hline SK 4 & tam(n)pa & semn(u)anya & m(n)afsu & pe(i)lihan \\
\hline & berfe(i)kir & p(b)erniaga & menarih(k) & remu(a)ja \\
\hline & Penggum(n)a & & & \\
\hline SK 5 & sed(b)agai & b(p)elbagai & nap(f)su & ra(e)maja \\
\hline SK 6 & tam(n)pa & $\begin{array}{l}\text { men(m) } \\
\text { promosikan }\end{array}$ & & \\
\hline SK 7 & at(l)at & tam(n)pa & b(h)ari & m(n)afsu \\
\hline & pe(i)lihan & peny(i)aga & ro(e)maja & \\
\hline SK 8 & $\begin{array}{l}\text { memen(r) } \\
\text { lukan }\end{array}$ & tam(n)pa & Mem(ng)ikut & \\
\hline
\end{tabular}

(Source: Field Research, 2012)

(6) Original sentence: Tanpa wang tidak dapatlah kita membeli barangan ...

SK 1 : tenpa wang tidak dapat lah kita membeli barangan-

gan ...

SK 2 : tampa wan tidak dapathah kita membeli maranan ...

SK 3 : tampai wang tidak dapat lah membeli barang ...

SK 4 : tampa wang ditidak dapatlah kita membeli baran gan ...

SK 6 : tampa wang tidak dapatlah kita membeli barangan

SK 7

SK 8$$
\text { ... }
$$$$
\text { : tampa wang tidak lah kita membeli barang ... }
$$$$
\text { : tampa wang tidak dapatlah kita membeli barangan }
$$

SK 1 had committed an error in sentence (6) above where he changed the word $<$ tanpa $>$ to become $<$ tenpa $>$. SK 1 replaced the letter $<a>$ to $<\mathrm{e}>$. In the detection of dyslexic symptoms, the letters $<\mathrm{a}>$ and $<\mathrm{e}>$ are categorized as similar letters in terms of their shape. Confusion in writing or verbalising the letters is contributing to the early detection of dyslexia.

Meanwhile, SK 2, SK 3, SK 4, SK 6, SK 7, and SK 8 as referred to sentence (6), had also mispelt the word <tanpa>. All six SK had spelt $<$ tanpa $>$ as $<$ tampa $>$. The confusion in the letters $<m>$ and $<$ n $>$ is also common among children who have just recognized the letters and are new to the syllables. However, the errors done by SK left a great impact on their writing, as they are not children who are new to letters and alphabets, but they are children aged 11 years old. Following their age maturity, they are supposed to be good at spelling easy and difficult words, but six out of eight SK had committed the same spelling error on the same word. 


\section{Reversal}

Reversal as an error is categorized into letter reversal and word reversal. It is common for dyslexic children to make this kind of error such as the letter $\langle$ b $>$ becoming $<\mathrm{d}\rangle$ or $\langle$ p $\rangle,\langle$ p $>$ becoming $\langle\mathrm{q}\rangle,<\mathrm{m}\rangle$ becoming $\langle\mathrm{w}>$, also $<\mathrm{n}>$ becoming $\langle\mathrm{u}\rangle$. The reversal of syllables for instance in the word $<$ tisu $>$ becoming $<$ suti $>$, $<$ buka $>$ turning into <kabu $>$, and $<$ buta $>$ reversed into $<$ tabu $>$ (Dyslexia Checklist Instrument Manual, 2011).

\section{Table 1.4: Error Analysis in terms of Reversal}

\section{\begin{tabular}{l|l|l|l|} 
SK 7 & adakha(ah) & sekarda(dar) & mempor(pro) \\
mosikan
\end{tabular}}

\section{(Source: Field Research, 2012)}

It is further found that two out of eight SK had made four mistakes in the reversal aspect. This is because almost all SK can make the syllable detection mentioned, and can spell and write properly. The errors done by SK 4 and SK 5 show that they had used their existing knowledge and gave alternative answers for something that had confused them (Brenna, 1995).

\section{(7) Original Sentence}

mengikut nafsu?

SK $7 \quad$ :... kerpeluan atau sekarda mengikut mafsu?

(8) Original Sentence

Peniaga berlumba-lumba mempromosikan barangan mereka.

SK 7 : penyaga berluba-lumba mempormosikan barangan mereka.

Referring to Table 1.4, the analysis shows that there were three mistakes on the spelling done by SK 7. The words concerned are $<$ sekadar>, and <mempromosikan>. SK 7 had reversed the position of the letter on the final syllable and the second part of the word. SK 7 had spelt the word <sekadar $>$ as <sekarda $>$, and also $<$ mempromosikan> becoming <mempormosikan>.

For the words <sekadar> and <mempromosikan>, the spelling done by SK 7 was influenced more by the verbal and use of Terengganu dialect. For the word <sekadar $>$ in the said dialect, they only pronounced it as /se.ka.da/, but when it was to be standardised, they often said it as /se/kar.da/ by dropping the letter $<r>$ on the final syllable and adding the letter $<r>$ on the second syllable of the word. Looking at the spelling error in the word $<$ mempromosikan $>$ it was also committed by SK 7 as he spelt it as <mempormosikan>, indirectly showing the influence of the dialect in the spelling. Verbally, the people of Terengganu pronounce the word /mempromosikan/ as /mempomosikan/, which is by eliminating the letter $/ \mathrm{r} /$.

We have acknowledged the fact that dyslexic children are those who are easily influenced and adhere to daily activities in their lives so much so that the activities are absorbed into their language mastery in the form of their writing. Therefore, activities which give exposure and meaningful experiences in terms of the academic acceptance must be given priority. Children who lack the exposure are more inclined to have problems in spelling, writing and reading (Snow et.al. 1998).

\section{Wild Guess}

Frequently, we find that dyslexic children cannot copy the words correctly, either from the blackboard or the book, and with limited concentration, a problem associated with visual judgement. They even find it a problem to discern the sounds of letters, syllables or words (Drake, 1989). Thus, in this research, we find that SK write purposelessly in the use of Capital letters and small letters. They also blindly guess the words, based on how pleasant the word sounded, and the sound felt 'right' when they hear and pronounce the particular word.

Table 1.5: Error Analysis in terms of Wild Guess

\begin{tabular}{|l|l|l|l|l|}
\hline SK 1 & $\begin{array}{l}\text { B(b) } \\
\text { erberlanjalah }\end{array}$ & b(B)ijak & ibu B(b)apa & t(T)enpa \\
\hline & S(s)ejumlah & a(A)dakalanya & puS(s)at & keP(p)erluan \\
\hline & nafsul & b(B)iasanya & o(O)leh & j(J)adilah \\
\hline
\end{tabular}

\begin{tabular}{|c|c|c|c|c|}
\hline SK 2 & dengang (3) & b(B)ijak & masis(h) & $\begin{array}{l}\mathrm{P}(\mathrm{p}) \\
\text { endapatan }\end{array}$ \\
\hline & $\begin{array}{l}\text { memerlum(k) } \\
\text { an }\end{array}$ & P(p)enukaran & dapath(I)ah & keP(p)utusan \\
\hline & $\begin{array}{l}\text { ibu baP(p) } \\
\text { a (3) }\end{array}$ & semb(j)umlah & keP(p)erluan & P(p)ilihan \\
\hline & $\begin{array}{l}\text { menge(i) } \\
\text { kok(ut) }\end{array}$ & $\operatorname{atauP}(p) u n$ & $\begin{array}{l}\mathrm{P}(\mathrm{p}) \\
\text { erasanga(n) }\end{array}$ & $P(p)$ erlu \\
\hline & $\begin{array}{l}\text { memP }(p) \\
\text { unya }\end{array}$ & $\operatorname{tam} P(p) a$ & & \\
\hline \multirow[t]{3}{*}{ SK 3} & b(B)ijak & memerilukan & inli (ingini) & $\begin{array}{l}\text { Adakalayang } \\
\text { (nya) }\end{array}$ \\
\hline & I(i)bu bapa & $\mathrm{P}(\mathrm{p})$ usat & $\begin{array}{l}\text { berbajah } \\
\text { (pelbagai) }\end{array}$ & berbelanjan \\
\hline & $\begin{array}{l}\mathrm{P}(\mathrm{p}) \\
\text { endapatan }\end{array}$ & P(p)erlu & & \\
\hline \multirow[t]{2}{*}{ SK 4} & b(B)ijak & $\begin{array}{l}\text { Menp(m) } \\
\text { erlukan }\end{array}$ & w(W)ang & $\begin{array}{l}\text { digunaleam } \\
\text { (kan) }\end{array}$ \\
\hline & S(s)ebagai & & & \\
\hline SK 5 & b(B)elanjalah & b(B)ijak & H(h)ari & $\begin{array}{l}\text { perninyaraga } \\
\text { (perniagaan) }\end{array}$ \\
\hline SK 6 & b(B)ijak & ingin ni (ingini & nak(f)sul & \\
\hline \multirow[t]{2}{*}{ SK 7} & b(B)elanjalah & $\mathrm{b}(\mathrm{B}) \mathrm{ijak}$ & $\begin{array}{l}\mathrm{KeP}(\mathrm{p}) \\
\text { utusan }\end{array}$ & $\begin{array}{l}\text { Sesatuan } \\
\text { (sesuatu) }\end{array}$ \\
\hline & ikelam(n) & & & \\
\hline SK 8 & b(B)ijak & perasa(a)ng & aK(k)an & na(f)sut \\
\hline
\end{tabular}

\section{(Source: Field Research, 2012)}

\section{Misused letters $<$ B $>$ dan $<$ b $>$.}

(9) Original sentence: Berbelanjalah dengan Bijak (Spend wisely)

SK 1 : berberlanja lah dengan bijak

SK 2 : Berlajalah denang bijak

SK 3 : Berlanjalah dengan big/jak

SK 4 : Berbelanjarlah dengan bijak

SK 5/7 : berbelanjalah dengan bijak

SK 6 : Berbelanjalah dengan bijak

SK 8 : Belajarlah dengan bijak

Sentence (9) below is a title of a text made as research material, which is "Berbelanjalah dengan Bijak". Thus, in the beginning of every word in the title it has to be written with a Capital Letter. Referring to sentence (9), all SKs had made the same mistake, which is the error in using small letters at the beginning of the word in the title-writing. SK 1, SK 5, and SK 7 had started with a $<$ b $>$ for the word $<$ Berbelanja $>$ becoming $<$ berbelanja $>$. Meanwhile, SK 2 , SK 3 , SK 4, SK 6 , and SK 8 had begun with the word $<$ Bijak $>$ by using the letter $<$ b $>$ which is from $<$ Bijak $>$ to $<$ bijak $>$. In terms of wild guess, researcher only looks at spellings that may be influenced by wild guesses done by the SK. Meanwhile, the error of the spelling system done by SK was categorized by the researcher into varying aspects of error.

\section{Condensation}

The outcome of the analysis finds that there was no condensation process done by SK. The combination of several words in the creation of new words was not done by SK. Conclusively, in the Malay Language essay-writing, SK did not make any mistake in the condensation aspect.

\section{CONCLUSION}

Normally, dyslexic children will have problems in several aspects, which are phonology, difficulty in memorizing words, in serial arrangements, short-term memory, and syntax awareness. The detection of these problems enable one to categorize a child either to suffer from dyslexia-visual, dyslexia-auditory or dyslexia visual-auditory problem. Abd. Rahim Talib (2006), states that children with special needs who suffer from incapability will leave a great impact on their normal lives and learning due to their deteriorating cognitive development. It is anticipated that both teachers- mainstream and special education teachers especially in dyslexia classes can strengthen their collaborations so as to achieve more effective teaching and learning through the input given towards special education administration especially for students who have some learning difficulties. Additionally, with consistent partnership, children with special needs will then be included into the mainstream based on the academic readiness criteria, and their condition 
will improve with the expertise and support offered by special needs teachers (Lee, 2010).

\section{REFERENCE}

Abd. Rahim Talib. (2006). Pengenalan Pendidikan Kanak-kanak Masalah Pembelajaran. Kuala Lumpur: MeteoDoc. Sdn. Bhd. | Barnard, P.A., Crewther, S.G. \& Crewwther, D. (1996). Visual Processing and Dyslexia. Clin Exp. Optom. 79:19-29. | Daniels, H. (2009). Vygotsky and inclusion. Dlm. Hick, P., Kershner, R. \& Farrell, P. (pnyt.) Psychology for inclusive education: new directions in theory and practice. HIm. 24-37. Oxon: Routledge. | Delphie. (2006). Pembelajaran Anak Berkebutuhan Khasus: Dalam Setting Pendidikan Inklusi. Bandung: PT Refita Aditama.| Drake, C. (1989). The terminology trap. Dlm. R.E. Cocen, \& J. C. Needly (pnyt) Learning disability law: New York: Committee on Juvenile Justice, Dyslexia and other Language Disabilities of the Appellate Division of the New York. | Hammond, L. \& Hugges, P. (1996). When bright kids fail: how to help children overcome specific learning difficulties. Australia: Simon \& Schuster. IJulie Williams \& Michael C O’Donovan. (2006). The Genetics of Developmental Dyslexia. European Journal of Human Genetic, 14, 681-689. Nature Publishing Group.| Kamus Dewan Edisi Keempat. (2005). Kuala Lumpur. Dewan Bahasa dan Pustaka. | Kementerian Pelajaran Malaysia. (2010). Pembangunan Pendidikan 2001-2010: Perancangan Bersepadu Penjana Kecemerlangan Pendidikan Malaysia: Malaysia Education Ministry. | Lee Lay Wah. (2008). Pembinaan dan Pengesanan Ujian Bacaan untuk Mengenal Pasti Masalah Membaca Disleksia. Doctoral Thesis Dissertation. Bangi: Universiti Kebangsaan Malaysia.| Lee, L.W. (2010). Different strategies for embracing inclusive education: a snap shot of individual cases from tree countries. International Journal of Special Education 25(3): 98-109. | Levinson, H. N. (1994). A Solution to the Riddle Dyslexia. New York: Springer-Verlag. | Livingstone, M.S., Rosen, G.D., Drislane, F.M. \& Galaburda. A.M. (1991). Physiological and anatomical evidence for a magnocellular deficit in development dyslexia. Proc. Natl Acad Sci. USA 88: 7943-7947.| Lovegrove, W.J., Bowling, A., Badcock, D., \& Blackwood, M. (1980). Specific reading disability: differences in contrast sensitivity as a function of spatial frequency. Science 210:439-440.| Madhya Zhagan. (1999). Kesan Pendekatan Pengajaran di Kalangan Pelajar DyslexiaBerumur 8 dan 9 Tahun di Kelas Pemulihan. Masters' Thesis Dissertation in Education. Bangi: Universiti Kebangsaan Malaysia. | McLeskey, J., Rosenberg, M.S., \& Westling, D.L. (2010). Inclusion: effective practices for all students. New Jersey: Pearson Education. | Mercer. (1997). Applying effective instructional strategies for teaching dyslexia students in a remedial collage algebra course. University Oregan: Annals of Dyslexia (45) 143-160. | Pelan Induk Rancangan Pendidikan (PIPP). (2010). Bab 7: Merapatkan Jurang Pendidikan. Pelan Induk Perancangan Pendidikan 2006-2010. http://www.moe.gov.my (12 September 2012) | Snowling, M.J, (1996). Dyslexia: a hundred years on. British Medical Journal, 313:1096-1097 (2 November) | Spafford, C.S. \& Grosser, G.S. (1996). Dyslexia Research and Resource Guide. | Stein, I. \& Walsh, N. (1997). To see but not to read, the magnocellular theory of dyslexia. Journal of Trends Neorosci 20: 147-152. | Wold Federation of Neurology. (1968). Report of research group n Dyslexia on the world illiteracy. Dallas: WFN. | Yusof Hj. Malie \& Walter Alvin Jiniti. (2010). Disgrafia dan Cara Membantu: Kajian Kes ke atas Murid Program Integrasi Pendidikan Khas. Jurnal Pendidikan Tindakan. Kuching: Institut Pendidikan Guru Kampus Batu Lintang. Volume 4: 1-22. II 